総説 第 $29 \cdot 30$ 回教育研修会 $(2008$ 年口腔四学会合同研修会 $)$

説「デンタルインプラントの基本とその応用」

\title{
骨移植および歯槽骨延長による歯槽骨造成法
}

\author{
森良之

\section{Alveolar ridge augmentation by bone grafting and distraction osteogenesis}

MORI Yoshiyuki

\begin{abstract}
Alveolar ridge augmentation by bone grafting has been carried out for a localized alveolar ridge defect to complete oral rehabilitation with endosseous implants. This procedure has several disadvantages, such as morbidity of the donor site or lack of soft tissue. On the other hand, distraction osteogenesis makes it possible to augment an alveolar ridge without bone grafting and allows simultaneous soft tissue expansion. Therefore this technique seems to be useful for alveolar ridge augmentation in patients undergoing dental implant treatment. However, in this procedure, several problems still remain such as infection or resorption of transport segment. Consequently we should make a deliberate choice for alveolar ridge augmentation.
\end{abstract}

Key words: alveolar ridge augmentation（蒾槽骨造成法），bone grafting（骨移植術），distraction osteogenesis（骨延 長術)

緒言

近年, 欠損歯の咬合機能の回復の手段としてインプラン 卜補綴は広く臨床応用されている. しかし，インプラント を埋入するためにはその土台となる菊槽骨に十分な骨量が 必要であるため, 柬槽骨量が不足している症例では，骨造 成法が考慮されなければならない。柬槽骨量の不足は, Seibert の㐘槽骨欠損の分類（図 1）を用いて，I型：㐘槽 堤の幅の喪失，II 型：柬槽堤の高さの喪失抢よび而型：柬 槽堤の高さと幅の喪失の 3 型に分けられ, 久損の形に合わ せた骨造成の方法が選択される ${ }^{1,2)}$.

㐘槽骨造成法には(1)自家骨移植，(2)人工骨補填剂を用い る方法, (3)メンブレンでスペースを作り骨誘導性のサイト カインによる骨造成を促進させる GBR 法（骨再生誘導 法), (4)柬槽骨延長術などがあり, これらを組み合わせた方 法も試みられている.

本稿では，どのような欠損の状態でも適応範囲が広く，

東京大学大学院医学系研究科外科学専攻感覚運動機能医学講 座口腔外科学分野

(主任：高戸 毅教授)

Department of Oral and Maxillofacial Surgery, Faculty of Medicine, Graduate school of Medicine, The University of Tokyo (Chief: Prof. TAKATO Tsuyoshi)
比較的安全で確実な方法と考えられる自家骨移植術に加 え, 近年顎骨にも広く臨床応用されている骨延長術の技術 を応用した歯槽骨延長術を用いた茵槽骨造成法について, 症例を提示し考察する.

\section{自家骨移植術}

顎骨の自家骨移植には, 主として海綿骨髄移植, 皮質海 綿ブロック骨移植，および血管柄付き骨移植の 3 種類が用 いられる。これらの移植骨は, 移植する部位や大きさによ って選択されるが，そのなかでも皮質海綿ブロック骨移植 はインプラント埋入のための歯槽骨造成に最もよく用いら れている.

症例 $1 ： 25$ 歳女性. 外傷による左側上顎側切柬欠損. 初 診時の口腔内所見およびパノラマX線所見から, 歯槽骨の 唇舌側の骨量の減少を認め (図 $\mathbf{2 a}, \mathbf{b}$ ), Seibert の柬槽骨欠 損の分類では class I と判断した。手術は歯槽骨欠損部の 粘膜に㐘槽頂から歯肉煩移行部へ切開し, 粘骨膜弁を挙上 して骨面を明示した後, 皮質骨にラウンドバーにて小孔を 形成し，移植床に血行を促した。採骨はオトガイ部から $10 \times 20 \mathrm{~mm}$ 大の皮質海綿ブロック骨を採取した（図 3a, 


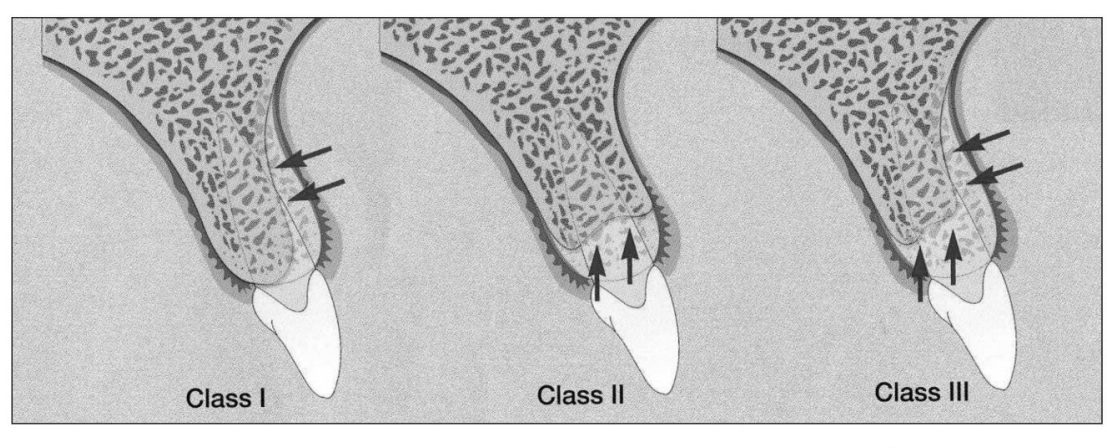

歯槽堤の幅の喪失 歯槽堤の高さの喪失 歯槽堤の高さと幅の喪失

図 1 Seibert の柬槽骨欠損の分類 (文献 6 より引用・改変)
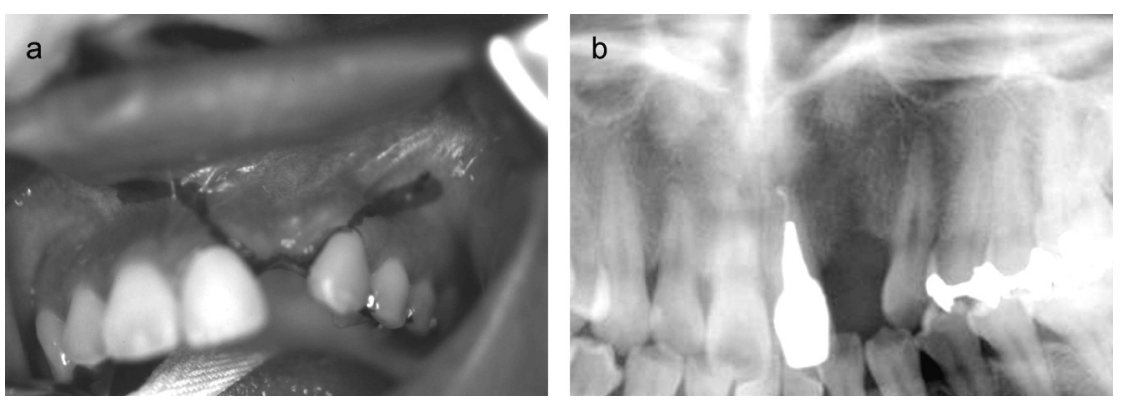

図 2

$\mathrm{a}:$ 症例 1 口腔内所見および切開線

$\mathrm{b}$ : パノラマX線写真像
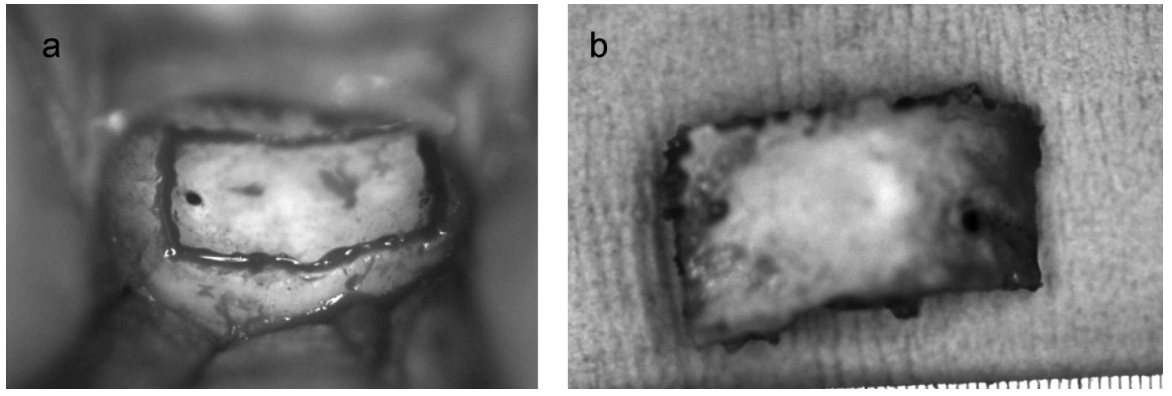

図 3

$\mathrm{a}$ ：オトガイ部採骨のデザイン.

b：採取した骨片 $(10 \times 20 \mathrm{~mm})$.

b).ブロック骨は，歯槽頂にあたる部分をトリミングし， 長さ $8.0 \mathrm{~mm}$ のマイクロプレート用スクリュー 1 本で骨片 を固定し，骨片周囲に海綿骨を緊密に充填し，閉創した (図 4)。骨移植後 3 か月で, 骨片固定スクリュー抜去と同 時に, インプラント（フィクスチャー）を埋入し, Tekを 装着した (図 $5 a, b)$. 移植骨の生着は良好で, 歯槽骨の幅 は増大していた. インプラント埋入後 3 か月で 2 次手術を
施行し, 補経処置を行い, 審美的にも良好な結果が得られ た（図 $6 a, b)$.

\section{歯槽骨延長術}

骨延長術は, 骨の治癒過程で形成される仮骨に外力を加 え，断続的に引き伸ばしていくことにより骨片間に骨を形 
成する方法であるが，同時に皮膚，筋肉，血管，神経などの 周囲軟部組織を拡張する効果がある。この方法を菊槽骨に 応用することにより, 吸収あるいは欠損した歯槽骨を垂直 方向または水平方向に造成することが可能となる. 本法は, 骨移植術のように採骨のために身体の他の健常な部位に新 たな創を形成する必要がないこと，また骨造成と同時に委

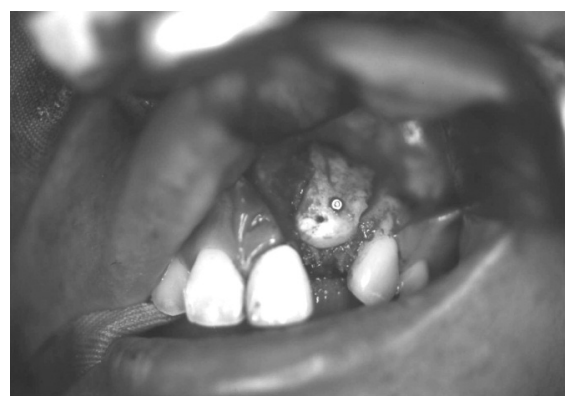

图４ママイクロプレート用スクリュー で骨片を固定し，骨片周囲に海綿骨 を緊密に充填した。
縮した歯肉や口腔粘膜を伸展することができることから， 歯槽骨の Ridge augmentationには有用と考えられる.

症例 $2 ： 28$ 歳男性. 上下顎前柬部柬槽骨欠損による咀 嚼障害および審美障害を主訴に当科へ来院した。 4 年前, 砕石機に挟まれて受傷し, 顔面多発骨折, 顔面正中部組織 欠損の診断のもと, 本院形成外科にて観血的整復術および 遊離複合組織移植術が施行されていた. 術前口腔内打よび X-P 所見では，上下顎とも前歯部の歯槽骨は，大きく欠損 していた。下顎前歯部の唇側㐘肉は欠如しており，植皮さ れていた（図 7a, b). 治療経過を図 8 に示す. 垂直型㐘槽 骨延長器（TRACK ${ }^{\circledR}$ ，KLS martin）を用いて柬槽骨延長を 行ったところ, 上下顎とも $6 \mathrm{~mm}$ の垂直的延長が得られ, 同部には骨形成が認められた（図 9a, b，10a，b)。しかし 上顎㐘槽骨延長では, 唇側方向への延長量の不足のため骨 移植が必要となった。垂直的柬槽骨延長を行った下顎前柬 部には径 $3.25 \mathrm{~mm}$ のインプラント (STERI-OSS ${ }^{\circledR}$; スレッ ド型，HA コーティング）を 4 本植立した. 垂直的歯槽骨 延長の後, 腸骨移植を行った上顎前柬部には, 径 $3.8 \mathrm{~mm} の$
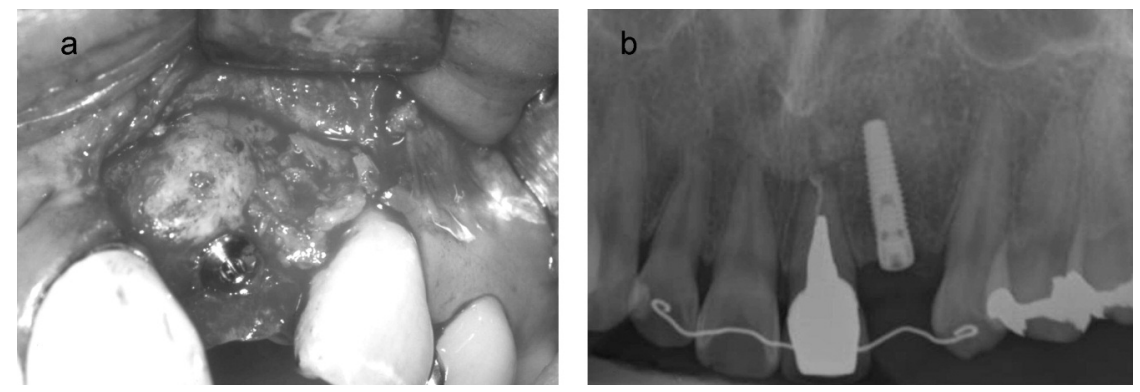

図 5

a : 骨移植後 3 か月. 移植骨の生着は良好であった。骨片固定スクリュー抜去

と同時に, インプラント；フィクスチャーを埋入した.

$\mathrm{b}$ ：同時期のスタータス X 線像.
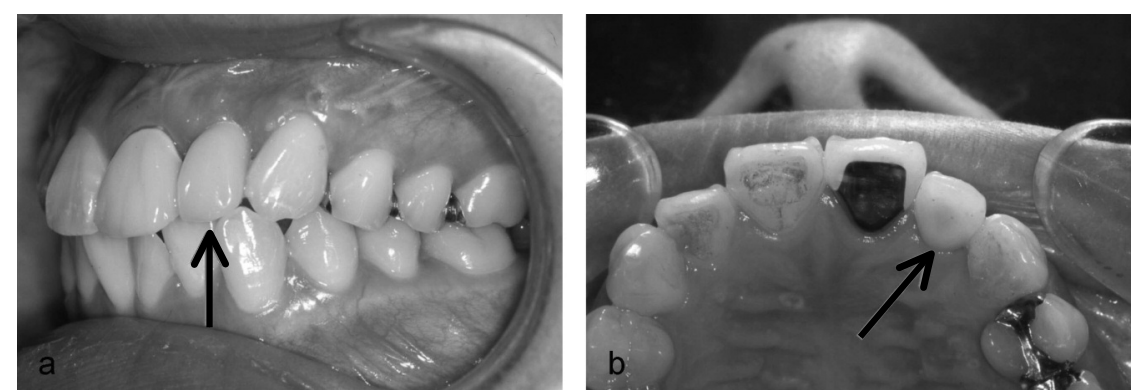

図 6

$\mathrm{a}, \mathrm{b}$ : 補綴処置 (フィクスチャー埋入後 3 か月).

矢印; 補経処置が終了した左側上顎側切柬. 

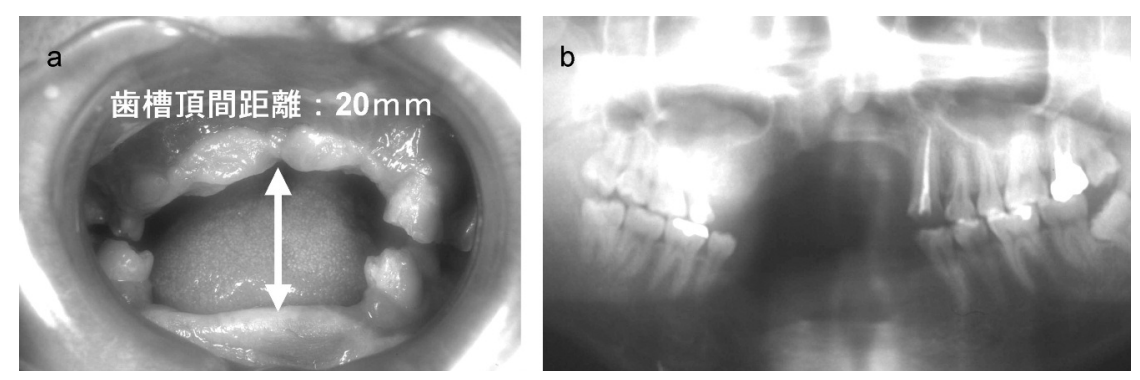

図 7

$\mathrm{a}$ : 症例 2 ; 上下顎とも前茵部の柬槽骨は欠損し, 下顎前柬部唇側柬肉は欠如 し植皮されていた.

$\mathrm{b}$ ：同症例のパノラマX線像を示す.

インプラント 4 本とその両側に径 $3.25 \mathrm{~mm}$ のインプラント (STERI-OSS ${ }^{\circledR}$, スレッド型, HA コーティング） 2 本を植 立した（図 11）。

\section{考察}

骨移植術において，移植骨の採取には，量的に制限があ るものの患者の負担が少ないオトガイ部（図 3) や下顎枝 外側（図 12）など ${ }^{3}$ ) からの口腔内採取と, 大量に採取可 能な腸骨に代表される口腔外採取があり（図 13）, 移植部 位，欠損の大きさ，範囲によって適宜選択される ${ }^{7)}$ (表 1) 移植骨の固定はチタン製マイクロプレート用のスクリュー を使用して $3 \sim 6$ か月間行われ，スクリュー除去と同時に インプラント埋入術が施行される.

骨移植術における移植部位の問題点として, 被覆粘膜の 不足から，減張切開を加えた創の閉鎖が行われるが，これ により口腔前庭が消失し, 口腔前庭形成術が必要となる場 合があることが挙げられる.

一方，こうした欠点を補う方法として骨延長術が応用さ れる. しかし，歯槽骨延長術に扔いても垂直・水平両方向 への同時延長は困難であること, 歯槽骨延長に使用する延 長器の一部は必ず口腔内に露出するため, 感染の危険性が あることなどの欠点がある.また, transport segment の大 きさによっては血行が不安定になる場合があり骨吸収の原 因となることを考慮しなければならない. 今回の症例 2 に おいて, 垂直的茵槽骨延長を行ったものの, 水平方向への 延長量の不足から追加的な骨移植術が必要となった. この 結果から考えて, 本症例では当初から骨移植術を行うべき であったかどうか, 議論のあるところである。しかし, 骨 延長によって菊肉が伸展したことで, 骨移植のスペースが 確保されたとも考えられ, 骨延長の有用性が示唆された ${ }^{8)}$. 延長器の種類は, 垂直方向の延長では, シリンダー部にマ イクロプレートが接合された形状で骨面に装着し, シリン

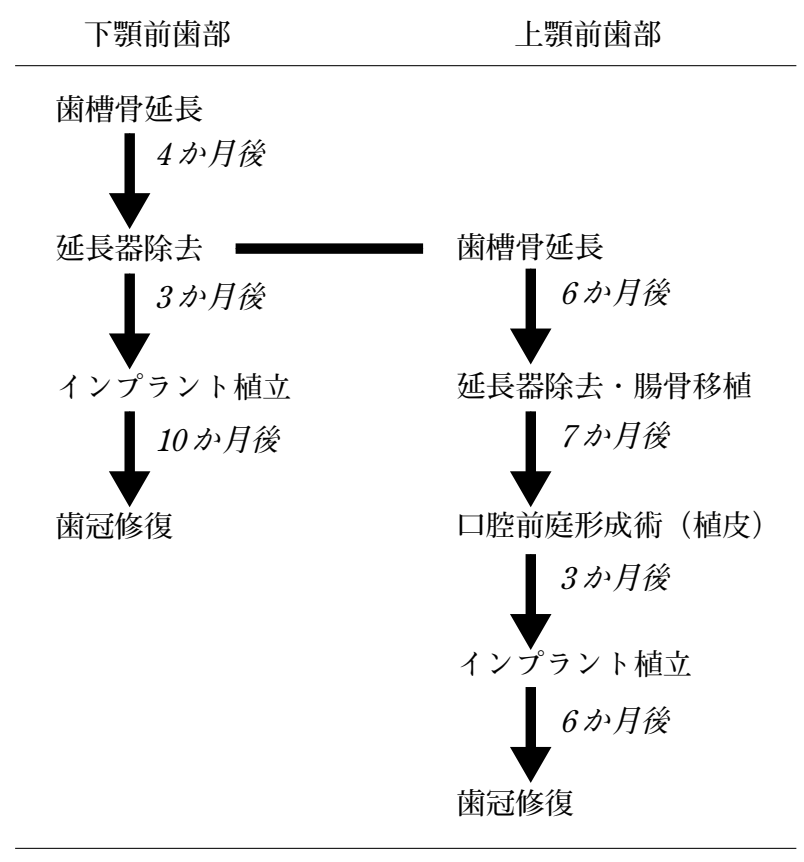

図 8 治療経過

ダー内部のトラックの回転で延長するプレート型（図 14: TRACK ${ }^{\circledR}$, KLS martin) や, 2 枚のプレートを骨切り部 の上下に装着し, 歯槽骨を貫通する延長用ロッドの回転で 延長するプレート複合型（LEAD SYSTEM ${ }^{\circledR}$, LEIBINGER) などがある ${ }^{4)}$.このほか延長終了後そのままインプラント 体として上部構造まで作製できるインプラント型がある. 一方, 水平方向の延長術には, プレート複合型（図 $15 ： ア$ ルベオ・ワイダー ${ }^{\circledR}$, オカダ医材 (株)）などが用いられて いる ${ }^{5,6)}$. 延長速度は $0.4 \sim 1.0 \mathrm{~mm} /$ day で, 延長終了後の 保定期間は $3 \sim 6$ か月間で, 延長器除去と同時にインプラ ント埋入術が施行される.

このように, 歯槽骨造成法に扎いて, 骨移植術扎よび骨 

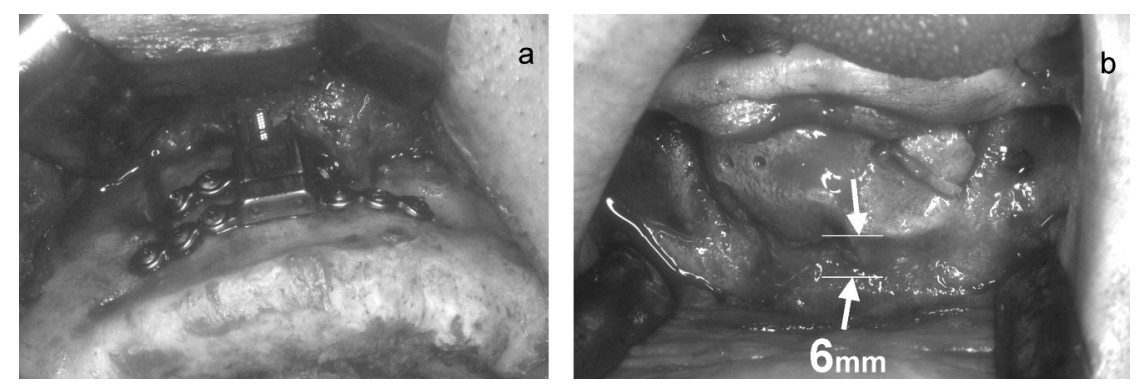

図 9

a : 下顎菊槽骨骨切り - 延長器装着.

b : 垂直的菌槽骨延長後.
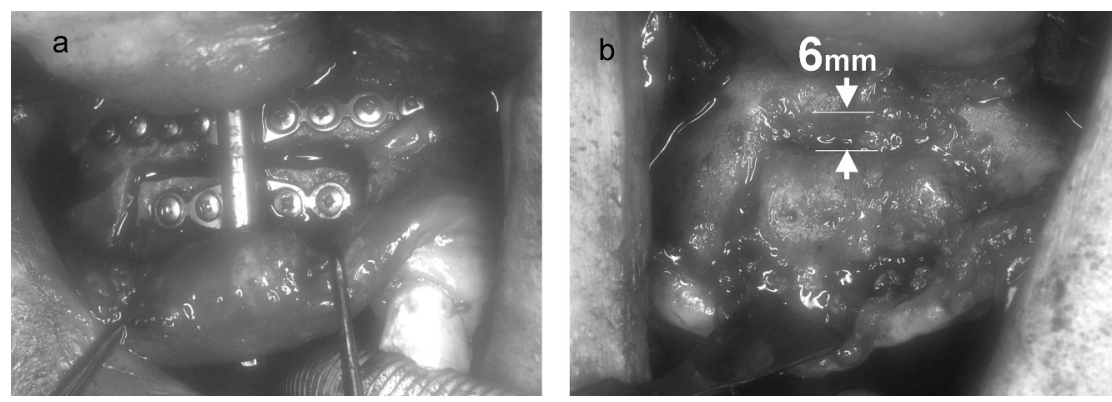

図 10

a : 上顎歯槽骨骨切り · 延長器装着.

b : 垂直的蒾槽骨延長後.
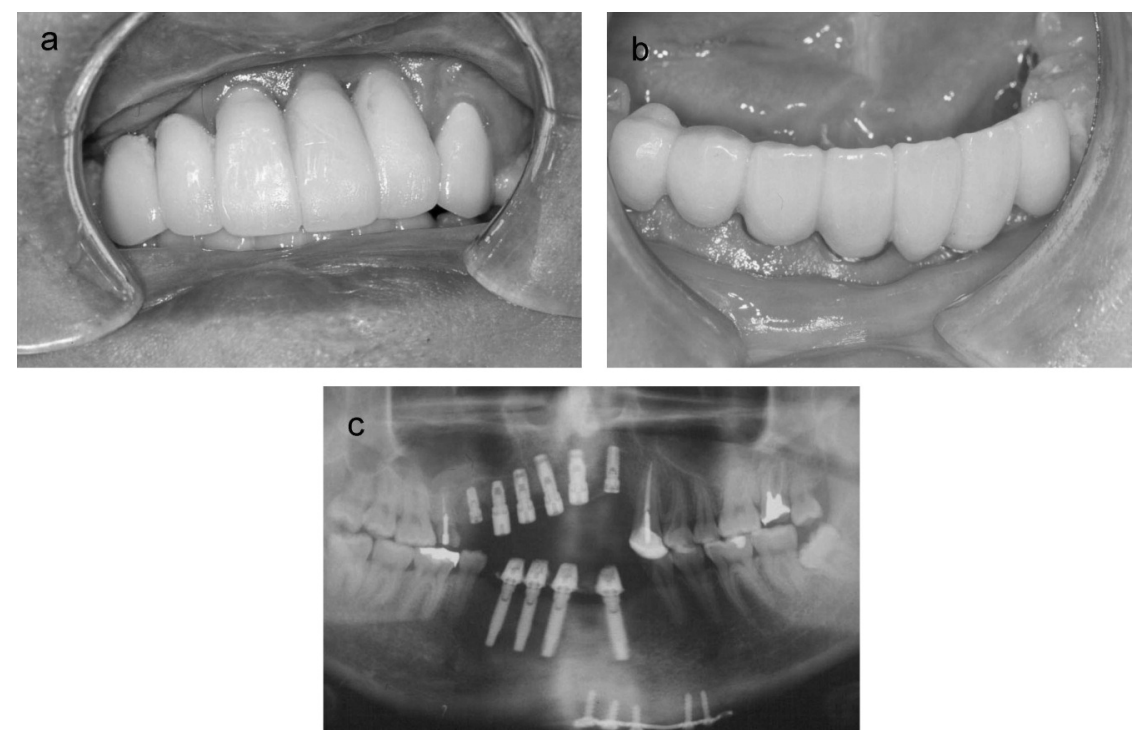

図 11

$\mathrm{a}$ ：上顎前蒾部；径 $3.8 \mathrm{~mm} \times 4$ 本打よびその両側に径 $3.25 \mathrm{~mm} \times 2$ 本 (STERI-OSS, スレッド型, HA コーティング).

b : 下顎前菊部 ; 径 $3.25 \mathrm{~mm} \times 4$ 本（STERI-OSS ; スレッド型, HA コーティ ング).

$\mathrm{c} ：$ パノラマX線像. 

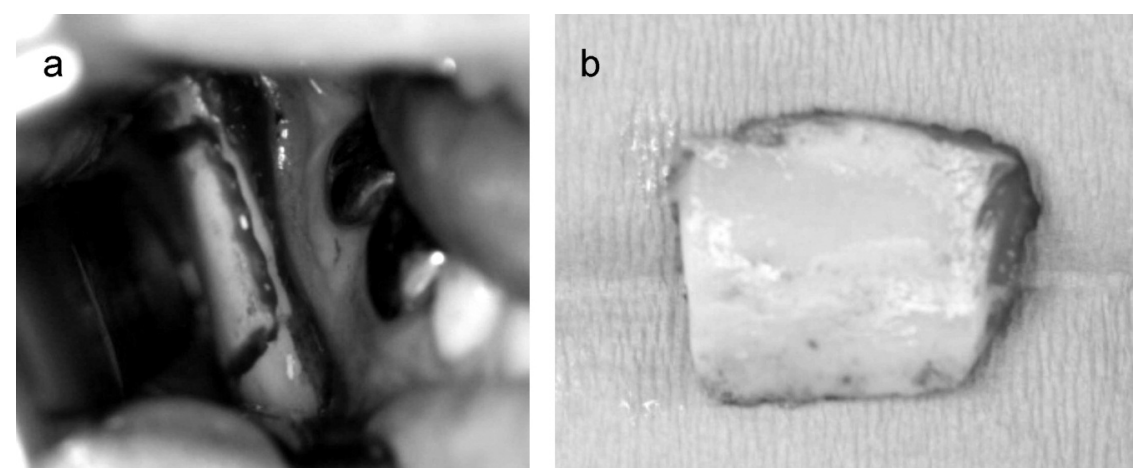

図 12

a : 下顎枝外側からの採骨の骨切り線.

b：採取した骨片。
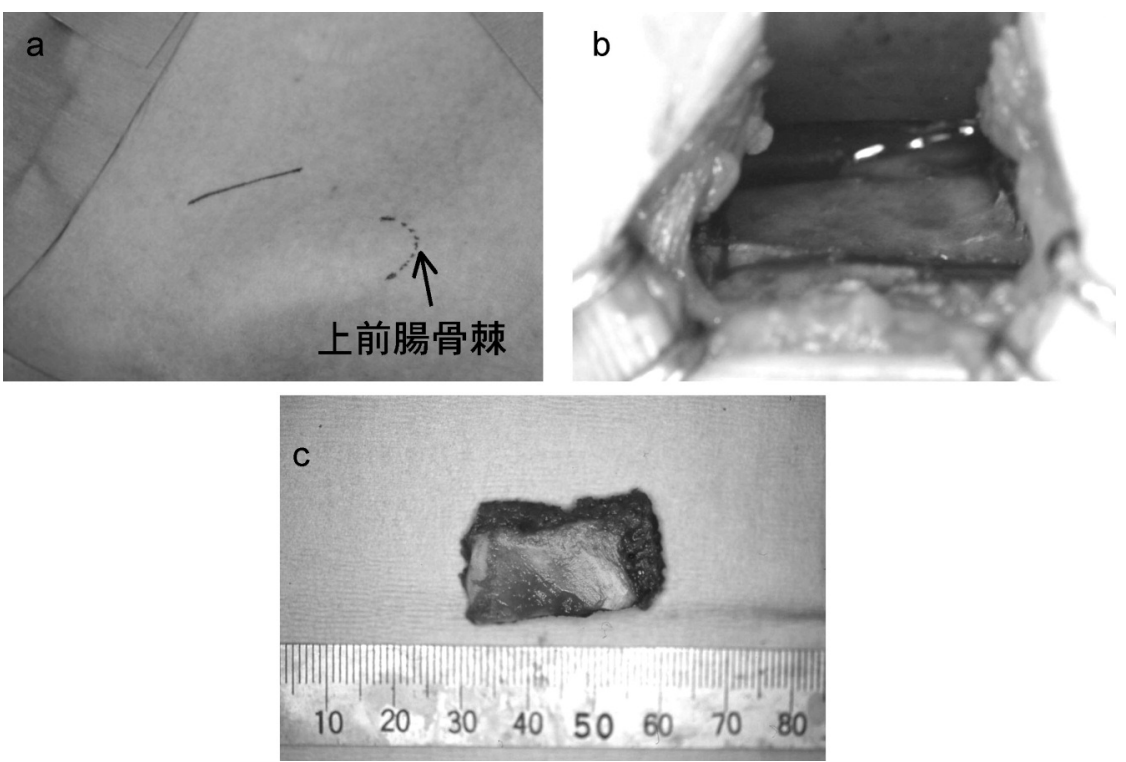

図 13

a : 腸骨採取時の皮膚切開.

b : 腸骨窩からの採骨の骨切り $(40 \mathrm{~mm}$ の皮膚切開から，30〜 40mm 四方の皮 質海綿骨ブロックとその周囲の海綿骨を採取できる).

c：採取した骨片。

表1 採骨部位による移植骨の比較

\begin{tabular}{|c|c|c|c|c|}
\hline 採取部位 & 発生学的分類 & 徵 & 採取量 & ドナー部位の主な合併症 \\
\hline 腸骨 & 軟骨性骨 & 皮質海綿骨 & 多量 & 疼痛、出血、感染、知覚異常 \\
\hline オトガイ部 & 膜性骨 & 皮質海綿骨 & 限定 & 知覚異常、歯髄生活反応変化 \\
\hline 下顎枝外側 & 膜性骨 & 皮質骨 & 限定 & 感染、知覚異常 \\
\hline
\end{tabular}




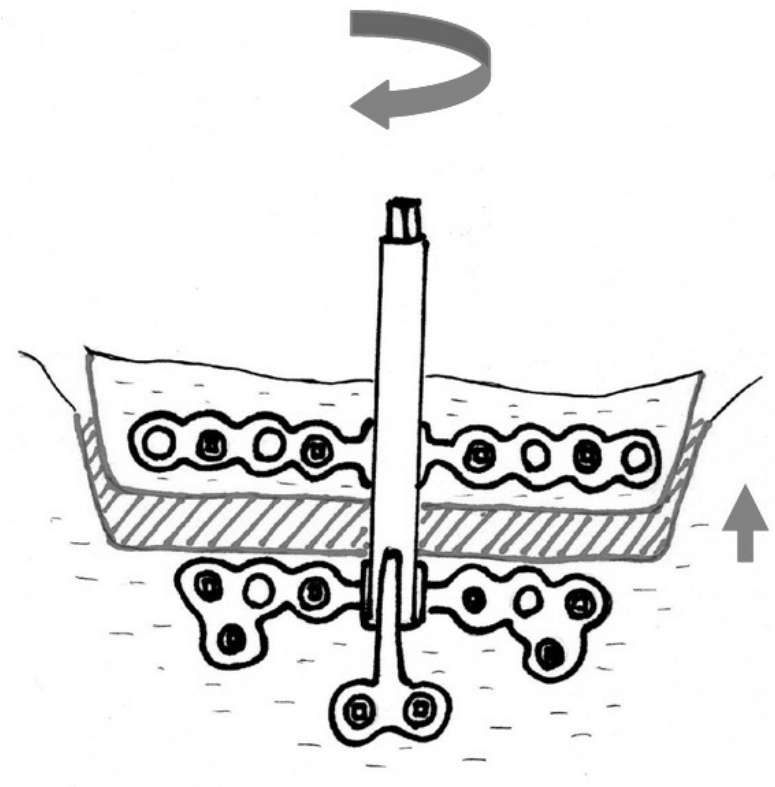

図 14 垂直的歯槽骨延長器

シリンダー部にマイクロプレートが接合された形状で 骨面に装着し，シリンダー内部のトラックの回転で延長 するプレート型延長器 (TRACK ${ }^{\circledR}$, KLS martin)
延長術のどちらの方法を選択するかは議論の多いところで あるが, 我々は現在のところ, 以下のような基準で歯槽骨 造成を行っている.

すなわち, 1 ～ 2 歯欠損に対する㐘槽骨造成には, 口腔 内採取による骨移植術を第 1 選択としている. また, 多数 柬欠損に対する柬槽骨造成では, 腸骨移植を用いている. 一方，㐘肉・粘膜萎縮の強度な柬槽骨欠損に対しては，柬 槽骨延長術が有用と考えられる.しかし, 感染の危険性と, 特に水平的歯槽骨延長に打ける transport segment の吸収 の危険性を考慮しなければならない。

\section{謝辞}

稿を終えるにあたり，インプラント治療を担当していただ いた新潟大学大学院医柬学総合研究科口腔生命科学専攻加歯 㐘科補綴学分野准教授富塚 健先生に深謝いたします.

\section{引用 文 献}

1) Sethi, A. and Kaus, T.: Ridge augmentation using
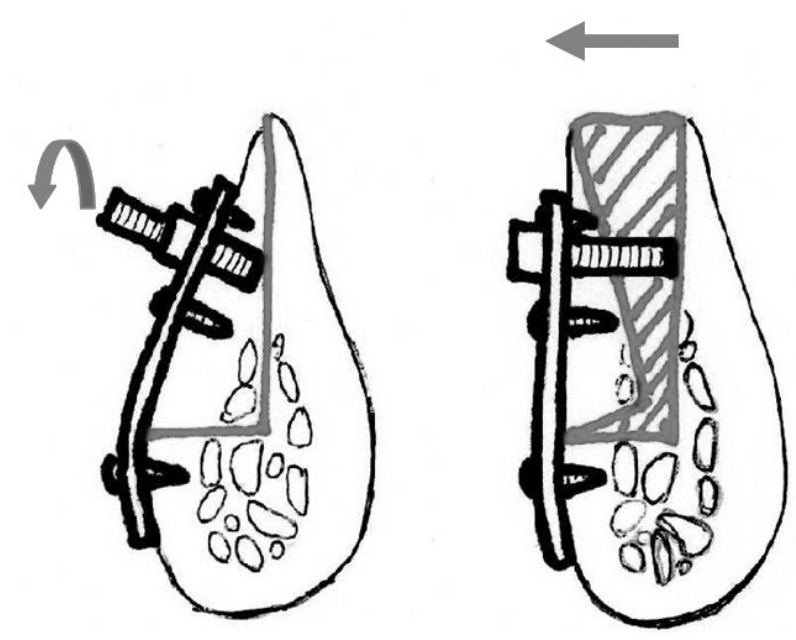

図 15 水平的柬槽骨延長器

弾力を有するチタン製メッシュプレートとその中央に 設置された distraction screw からなるプレート複合型延 長器（アルベオ・ワイダー ${ }^{\circledR}$; オカダ医材 (株)）

mandibular block bone grafts: Preliminary results of an ongoing prospective study. Int J Oral Maxillofac Implants 16: 378-388 2001.

2) Cohen, S.E.: Atlas of cosmetic and reconstructive periodontal surgery. 2nd ed, 1989, p233.

3）澤 裕一郎, 滝本 明, 他：インプラント治療に打 ける下顎曰㐘部から採取した自家煩側皮質骨移植に ついての検討. 日口外誌 52: 172-178 2006.

4) Chin, M. and Toth, B.A.: Distraction osteogenesis in maxillofacial surgery using internal devices: review of five cases. J Oral Maxillofac Surg 54: 45-53 1996.

5) Nosaka, Y., Kitano, S., et al.: Endosseous implants in horizontal alveolar ridge distraction osteogenesis. Int J Oral Maxillofac Implants 17: 846-853 2002.

6) 高橋 哲, 他：インプラント植立のための水平的柬 槽骨延長法. インプラントジャーナル ゼニス出 版, 2003, p34-47.

7）古賀剛人：インプラント外科学応用編。クインテッ センス出版, 2007, p108-131.

8）森 良之, 富塚 健, 他：垂直的骨延長による歯槽 堤形成術の経験 (第 3 報). 第 56 回日本口腔科学会 総会抄録集 p265, 2002. 